\title{
Research on the Seismic Response of Residential Buildings Located in Areas of High Seismic Risk in Cuba
}

\author{
Dalia Pupo ${ }^{1 *}$, Víctor M. Valdés ${ }^{1}$, Roberto Martínez¹, Rolando M. Fernández¹, Carlos A. Recarey² \\ ${ }^{1}$ Enterprise of Engineering Services and Design, Holguín, Cuba \\ ${ }^{2}$ Center of Studies of Computational Mechanics and Numerical Methods in Engineering, UCLV, Santa Clara, Cuba \\ Email: ^dalia.pupo@vertice.cu
}

How to cite this paper: Pupo, D., Valdés, V.M., Martínez, R., Fernández, R.M. and Recarey, C.A. (2019) Research on the Seismic Response of Residential Buildings Located in Areas of High Seismic Risk in Cuba. Open Access Library Journal, 6: e5854.

https://doi.org/10.4236/oalib.1105854

Received: October 14, 2019

Accepted: November 23, 2019

Published: November 26, 2019

Copyright $\odot 2019$ by author(s) and Open Access Library Inc.

This work is licensed under the Creative Commons Attribution International License (CC BY 4.0).

http://creativecommons.org/licenses/by/4.0/

\begin{abstract}
Probabilistic assessment expressed through analytical fragility curves of the multifamily housing buildings, located in the southeastern region of Cuba, is presented. Motivated by the latest update of the Cuban code for seismic resistance analysis of structures, NC 46:2017, which has been the object of important changes with regard to the seismic design approaches, the evaluation of the adequacy of existing structures becomes an imperative. Additional reasons that emphasize this need are related to the update of the seismic hazard map for Cuba dated 2017, in which the values of spectral accelerations have been significantly increased, compared to the normative in use at the date of these structures were erected. This fact justifies the seismic reassessment program of a large number of housing buildings located in high-risk areas. To express the structural response under seismic loading, the nonlinear procedures for seismic performance assessment of buildings which combine nonlinear static (pushover) analysis of entire structure and nonlinear response history analysis (NRHA) of an equivalent single-degree-offreedom (SDOF) model have been used. Finally, seismic behavior of one selected structural system through the analytical fragility curves is obtained.
\end{abstract}

\section{Subject Areas \\ Civil Engineering}

\section{Keywords}

Linear and Non Linear Analysis, Incremental Dynamic Analysis, Prefabricated Existing Buildings, Seismic Structural Analysis, Fragility Analysis, Collapse Limit State, Sustainable Habitat 


\section{Introduction}

Cuban code for resistance analysis of structures, NC 46:2017 [1], has been the object of important changes with regard to the seismic design philosophy for the new structures. Significant increases in the values of the seismic action intensity yielded by the latest seismic hazard analyses intended for the new normative are today of concern to many structural engineers of current practice. In this new normative, the spectral shapes are function of different hazard intensity levels, each one associated with a seismic protection category. These changes open new paths to incorporate the probabilistic criteria in the earthquake performance assessment of our structural systems, and will also enable the insertion of the reliability and risk-based estimates into the decision-making criteria for the rehabilitation and retrofit the existing buildings in Cuba. Among the structures of special interest, with respect to the safety evaluations, are the hospitals, tall housing buildings and schools, many of them built with typical structural systems developed in Cuba and other systems, such as the present case, with a technology transferred from the former Yugoslavia, since the 1970s to the 1990s, well known as IMS system (Institute of Materials of Servia).

\subsection{Social Insertion of the Investigation (Program and Project)}

The construction of buildings housing in Cuba had a vertiginous growth in the decades from 1965 to 1980, and aimed at satisfying this ambitious program, the Cuban Government had to develop new projects of precast structural typologies and also transfer constructive technologies from other countries. Thus began the dissemination throughout the country of typical structural systems designs with a few variations in the architectural solutions and non-structural elements. Many of these buildings were located in seismic zones and built from 1970s to 1990s according to the specifications of the old codes in use at the time. Today there are several reasons that justify its re-evaluation: one is the elapsed lifetime without an extensive revision, and the other is related to the update of the seismic hazard map for Cuba dated 2017, in which the values of spectrum accelerations have been significantly increased, compared to the normative in use at the date of its construction. So there exist the uncertainty if they meet the requirements of the new seismic standard.

\subsection{Research Motivation}

- At the moment of the research the problematic is the as follows:

- A large number of structural systems were built in the epoch of industrialization in Cuba, under old standards.

- Decision making is still based on the current deterministic characterization of the relationship Seismic Action-Structural Demand,

- The absence of a philosophy for seismic estimation of existing structures makes risk-based decision making difficult, consequently rehabilitation/retrofit of existing structures without adequate reliability-cost studies are undertaken. 
Two fundamental aspects are derived from all the aforementioned: 1) The need to incorporate risk criteria in the new building designs; 2) to predict the seismic resistance of the existing buildings typologies, which were built by the Cuban Government after 1959, with the purpose of extending its useful lifetime, based on structural safety criteria against collapse.

Taking advantage of the existence of structural archetypes for Cuba's housing buildings, which are replicated in many places, our focus was on characterize, by probabilistic estimation, the structural seismic response of a large number of structures based on the analytical fragility functions obtained from these archetypes. This can be considered as a first step in the contribution to the estimates of the collapse risk to making the decisions on a large scale.

\section{Selection of the Structural Typology under Study}

As an object of study, the tallest IMS residential buildings, located in the city of Santiago de Cuba, one of the most high-risk areas of our country, were selected. The IMS prefabricated system was developed in 1957 in the former Yugoslavia by Professor BrankoZezelj and was introduced to Cuba with the assistance of Yugoslavian technical staff from 1967. The buildings constructed with this technology have heights ranging from 5, 8, 12 and 18 levels as shown in Figure 1 (a), the latter being the most abundant.

\section{Description of the Structural Systems}

The basic project of the IMS structural system implemented in Cuba, for residential use, is a dual system, in which the frames and structural walls follow a simple modular grid of $4.20 \times 4.20 \mathrm{~m}$, as shown in Figure $1(\mathrm{~b})$. The precast elements of the skeleton are assembled by post-tensioning of the joints. Precast

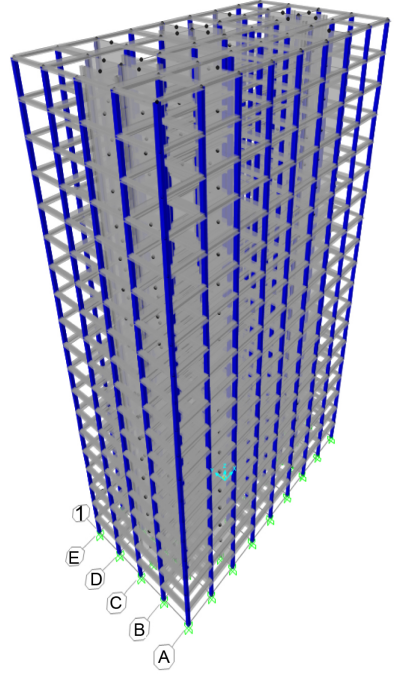

(a)

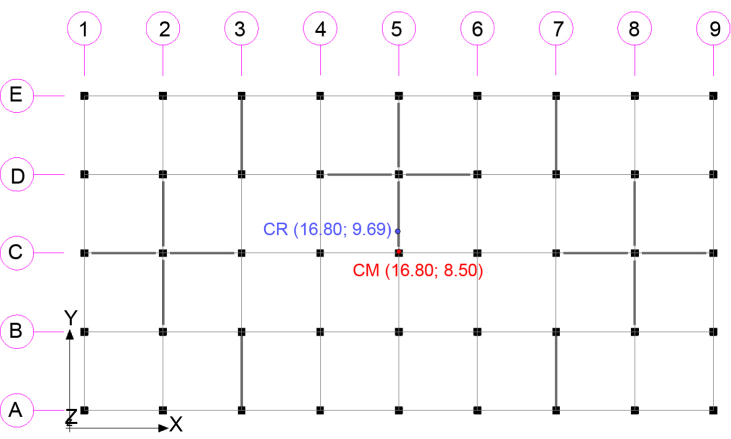

(b)

Figure 1. (a) Schematic 3D representation of the 19-story building; (b) Rigidity and mass center of typical floors in the structure. 
slabs will form into a monolithic whole by post-tensioned tendons (two strands of four wires of $7 \mathrm{~mm}$ diameter with polygonal tracing) which pass through ducts in the columns at floor slab level and along the gaps left between adjacent slabs. Other variants use 4 cables of straight tracing with 6 wires of diameter $5 \mathrm{~mm}$. The strength of the cables is given by a yield stress of $\sigma_{0.2}=1500 \mathrm{~N} / \mathrm{mm}^{2}$ and ultimate tensile strength of $\sigma_{r}=1700 \mathrm{~N} / \mathrm{mm}^{2}$. Once cast the ducts, with concrete of $35 \mathrm{MPa}$, make up the beams of $0.22 \mathrm{~m}$ depth that run in orthogonal directions.

The structural frame (columns and floors) was designed to take $25 \%$ of seismic forces. The columns are continuous over three levels, with sections of $0.38 \times$ $0.38 \mathrm{~m}$ in the cases of 18 -storey building and $4 \times 22 \mathrm{C} 400 / 500 \mathrm{~N} / \mathrm{mm}^{2}$ as longitudinal reinforcement steel. The static bearing capacity of these columns has been checked using the interaction diagram given in data provided by the layout of the original system.

The horizontal seismic loads are resisted mainly by prefabricated structural concrete walls of $15 \mathrm{~cm}$ thick, with side joints cast in situ, which are located between the columns to stiffen the frames from the foundation to the roof. The concrete strength of the main piers, columns, structural walls is $35 \mathrm{MPa}$. Figure 2 shows the different types of frame-wall arrangements along the longitudinal (a) and transverse direction (b) of the structure.

The waffle floor slabs with cast cover the space between columns and are connected to these through a special union slab-column post-tensioned. After prestressing the gaps between the slabs, tendons then become bonded within the spans, as shown in Figure 3(b). This effective pre-strength force, provides an anchoring force through the beam-column interface sufficient to withstand, by friction, dead load forces and live overload.
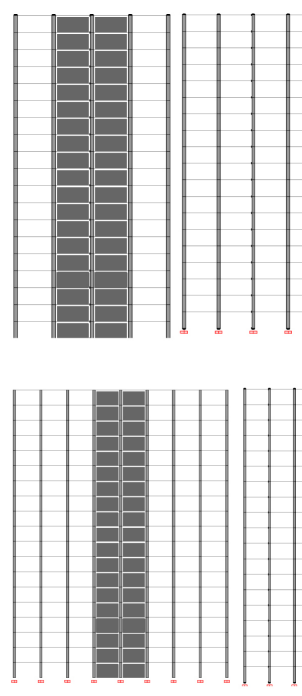

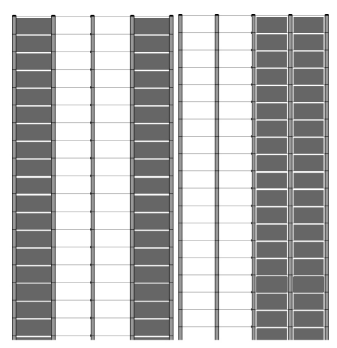

(a)

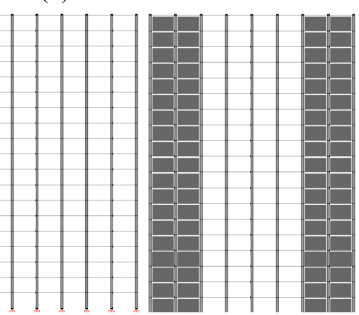

(b)

Figure 2. (a) Frames and frame-wall substructures along the Y direction of the building; (b) Typical frame and wall-frame substructures along the $\mathrm{X}$ direction of the building. 


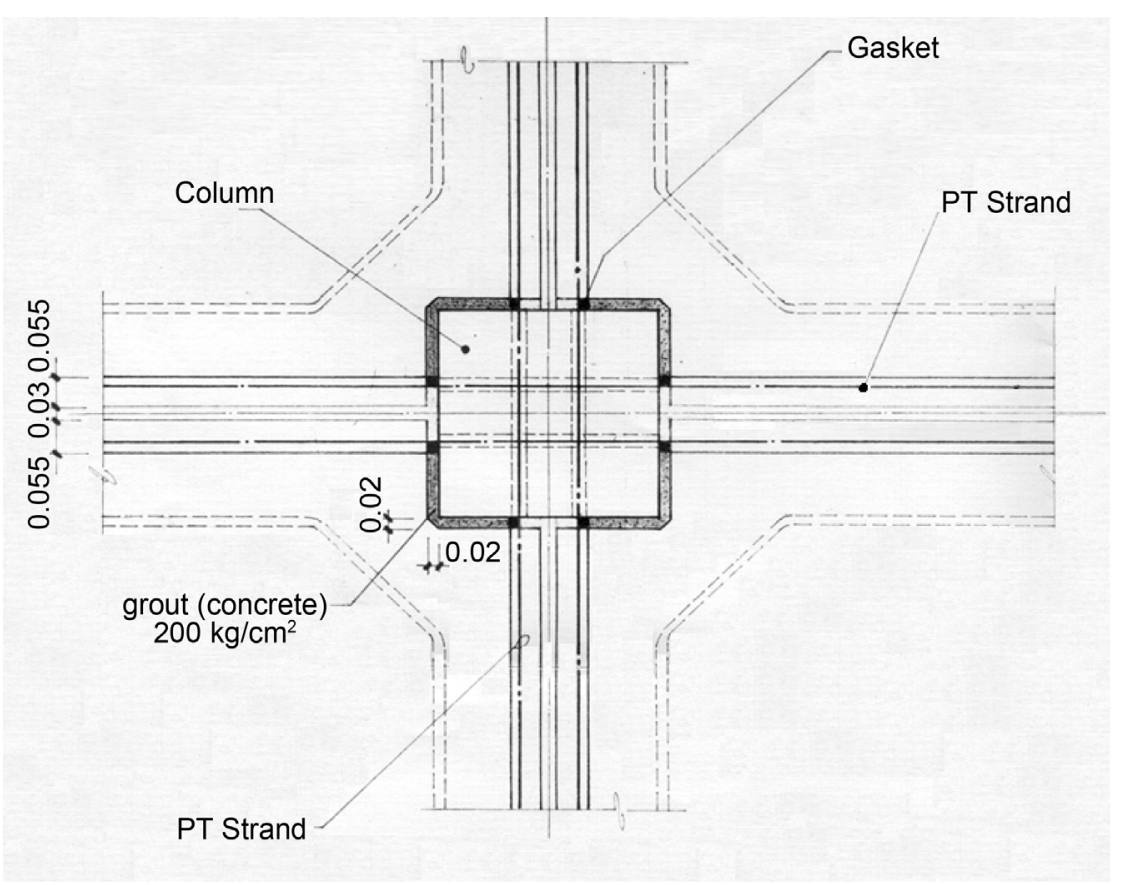

(a)

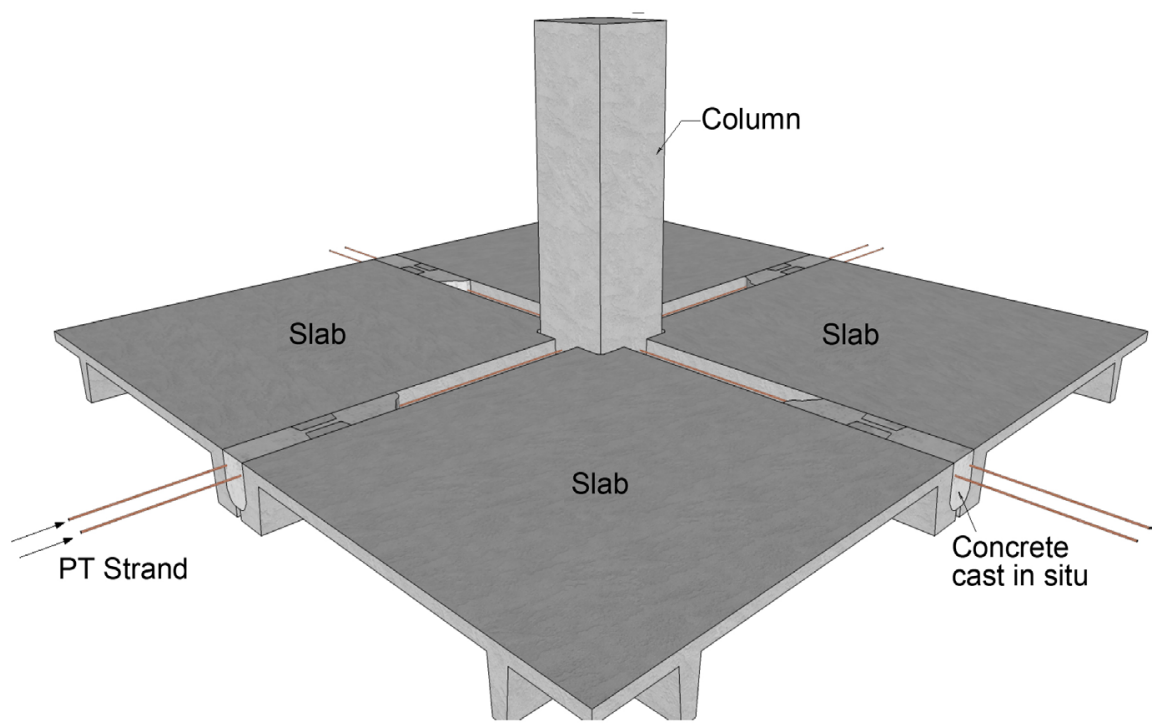

(b)

Figure 3. Details of special union slab-column using posttensioning of strands, (a) Top view of slab-column joint; (b) Isometric view of the beam section completion process by casting the horizontal joint and embedding the post-tensioning cables.

The foundation consists of a grille of inverted T-section beams (flat raft) cast in situ supported throughout their length, designed for a foundation depth of $3.10 \mathrm{~m}$ below the level of the grade. The geology of the region corresponding to the periphery of the Santiago de Cuba bay is characterized by rocks components of the marine terraces, abounding in the strata, below the foundation fragments of volcanic rock severely weathered and marl clay of consistency very severely weathered. 


\section{Dynamic Characteristics}

An analysis of the eigenvalues of the 3D elastic model of the structure executed on the REVSE platform and calibrated with SAP2000 software yielded a $92 \%$ of participation of the effective modal mass in the first nine vibration modes as shown in Figure 4.

As expected from Table 1, it was observed that due to a lightstiffness asymmetry in $\mathrm{X}$ direction, given by disposition of shear walls, the contribution to first mode amounted $60.56 \%$ of the effective modal mass in the $\mathrm{X}$ translational direction and $8.79 \%$, in the rotational direction $\mathrm{Z}$, something similar happened with the 3rd mode, while mode 2 , due to symmetry in the $Y$ direction, is almost translational, with the $67.98 \%$ of the effective modal mass participation.

\section{Selecting the Assessment Target of Existing Buildings}

The new Cuban Standard for seismic resistance analysis of structures, NC 46:2017 [1], is rather a design-oriented standard maintaining deterministic models approach. So, in this sense, some degree of conservatism could be involved in the assessment of existing buildings using current design approach of this code. The fact is that existing buildings assessment is often conducted according to the probabilistic format and it allow to find a lower acceptable performance level than that of the current design codes, based on fragility, reliability and risk (Holický M. et al. (2013) [2].
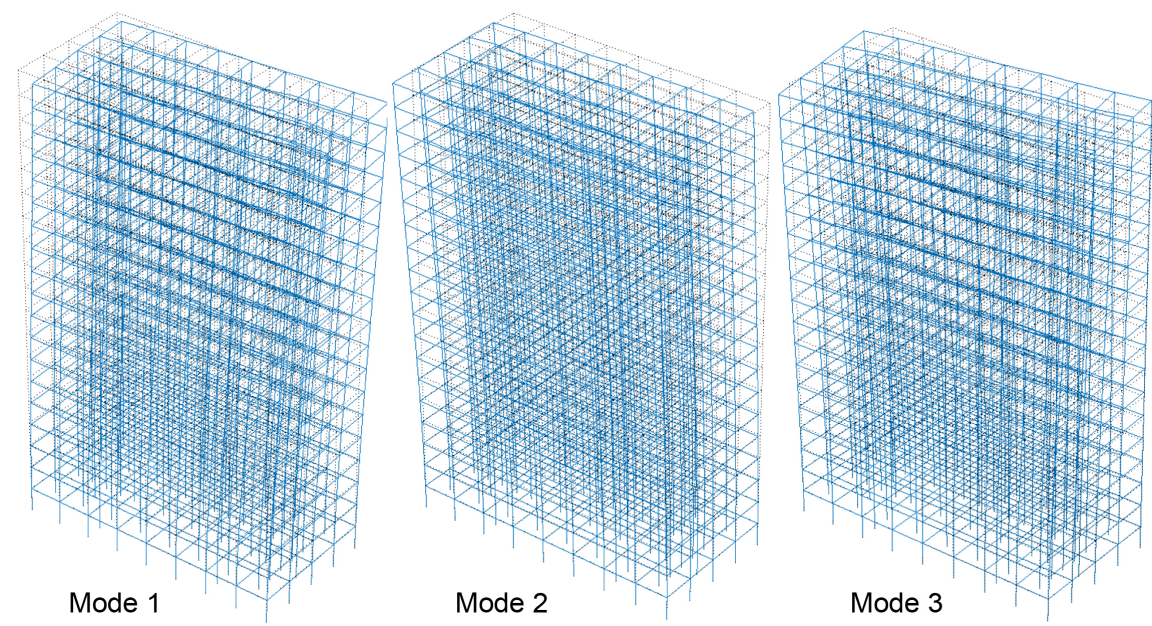

Figure 4. Modal response of the 3D structure, obtained in the REVSE program (developed by the authors).

Table 1. Dynamic characteristics of structure.

\begin{tabular}{ccccccccccc}
\hline & Mode1 (T1) & Mode 2 (T2) & Mode 3 (T3) & Mode 4 (T4) & Mode 5 (T5) Mode 6 (T6) Mode 7 (T7) Mode 8 (T8) Mode 9 (T9) \\
\hline Direction & $1.75 \mathrm{~s}$ & $1.58 \mathrm{~s}$ & $1.556 \mathrm{~s}$ & $0.434 \mathrm{~s}$ & $0.382 \mathrm{~s}$ & $0.371 \mathrm{~s}$ & $0.199 \mathrm{~s}$ & $0.173 \mathrm{~s}$ & $0.164 \mathrm{~s}$ & Total \\
$\mathrm{X}$ & 60.5558 & 0.0147 & 8.6685 & 14.7461 & 2.8032 & 0.1558 & 4.8502 & 0.8576 & 0.0793 & 92.7313 \\
$\mathrm{Y}$ & 0.0085 & 67.9807 & 0.2958 & 0.0322 & 0.3372 & 17.663 & 0.0191 & 0.095 & 5.8818 & 92.3132 \\
$\mathrm{Z}$ & 8.7947 & 0.2958 & 60.2074 & 2.7529 & 14.3479 & 0.2014 & 0.8986 & 4.8999 & 0.0537 & 92.4524 \\
\hline
\end{tabular}


In this study, the main interest was intended to verify the limit state of prevention of collapse, $\mathrm{CP}$, as these structures have already yielded good part of its lifetime span and, in many of the cases, they are exposed to aging and deterioration effects, so the criteria for rehabilitation must discard, in the first instance, the risk of imminent collapse under its actual structural condition.

Taking account the aspects aforementioned, the safety verification of multifamily housing buildings under the limit state of collapse prevention, CP, was defined as the main assessment goal in this study.

\section{Seismic Hazard}

Even when in Cuba, the frequency of devastating earthquake is relatively low compared to other Caribbean islands; the Santiago de Cuba city is exposed to high levels of seismic risk because of its tectonic setting. Located very close to the border between two tectonic plates, the Caribbean and North American plates, it is exposed to moderate to strong ground motions, being the Strike-Slip fault, the dominant rupture mechanism that more influence the earthquake hazard of emplacement site (Arango, 2014) [3]. The expected ground motion in the basement in Santiago de Cuba, coming from the so-called Oriente fault zone, has been studied by different authors (García, 2007) [4], (Alvarez et al., 2015) [5]. Estimates based on seismotectonic considerations show that the most likely strong earthquake is a ground motion of about Ms.8, as the maximum earthquake possible, MCE.

As shown in Figure Peak Ground Acceleration of $0.513 \mathrm{~g}$ is the predicted acceleration for Santiago de Cuba, by the new seismic hazard map (NC 46:2017) [1], which corresponds to a return period of 1642 years (MCE). The design spectrum corresponding to this seismic level can be seen in the (Figure 5(a)). NC 46:2017 defines as extreme earthquake, the one that has a 3\% chance of being exceeded in 50 years. The (Figure 5(b)) shows the spectrum for this $3 \%$ probability in 50 years on hard soil, soft rock characterized by Vs $760 \mathrm{~m} / \mathrm{s}$.

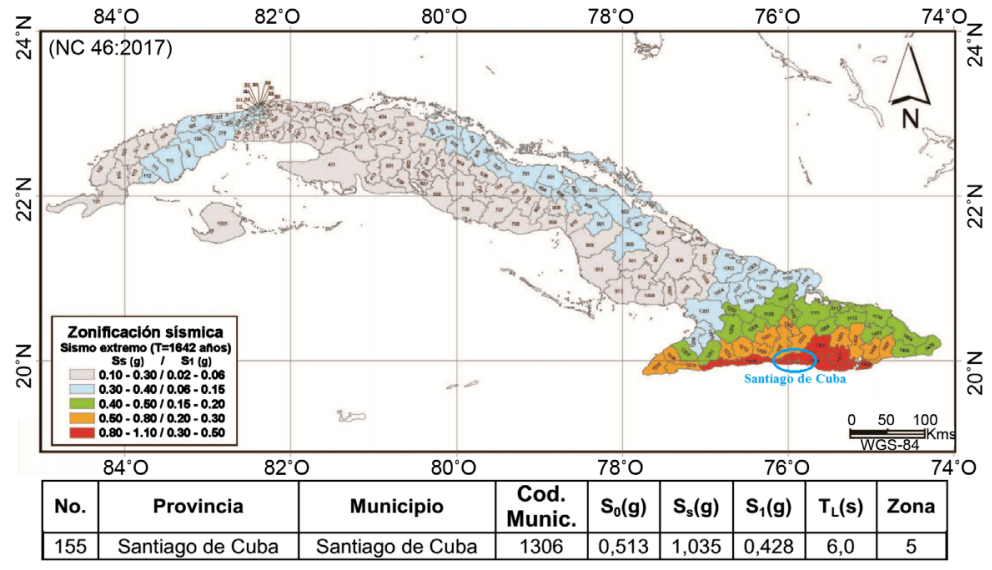

(a)

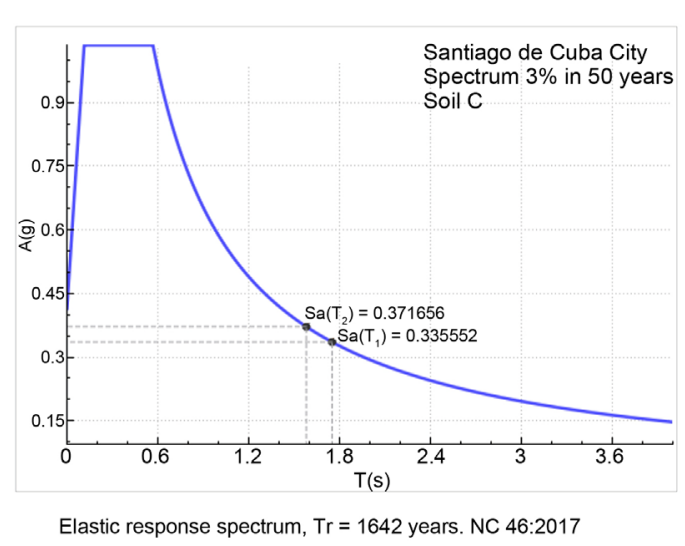

(b)

Figure 5. (a) Cuban seismic hazard map, with defined spectrum values for MCE on rock at the Santiago de Cuba city; (b) Design Spectrum for the city of Santiago de Cuba, on rock or very firm soil. $\mathrm{T}_{\mathrm{r}}=1642$ years. 
According to the engineering-geological research carried out in the area, these strata classify as very hard soils with a resistant soil capacity of $2.5-3.0 \mathrm{~kg} / \mathrm{cm}^{2}$ which, from the point of view of seismic regionalization, are considered type $\mathrm{C}$ soils. In NC46:2017 the Type C soils are characterized by weather soft rock profiles of any thickness or very dense soils with $360 \mathrm{~m} / \mathrm{s}<\mathrm{Vs} \times 760 \mathrm{~m} / \mathrm{s}$.

\section{Strong Motion Selection}

Criteria from different authors was revised [6]-[12] for the purpose to select the hazard-compatible ground motions to be used in nonlinear dynamic analysis of structural model. Several selecting and scaling ground motions procedures was analyzed and finally, a computational algorithm (SEHTA) developed by the authors in $\mathrm{C}^{++}$-Matlab, targeted tosearch, select and scaling ground motions according to different criteria was used to match the response spectrum of the Santiago de Cuba city. Oneset of records were defined as the most probable seismic environment in the zone represented by far field records (Figure 6(a)). Selecting Strike-Slip ground motions was made from the data base PEER [13] and ISESD data bank [14]. Forty-six records were selected considering scenario characterized by $6.5<\mathrm{M} \leq 7.5,21<\mathrm{R} \leq 150$, Kmand $300 \leq \mathrm{Vs}<800 \mathrm{~m} / \mathrm{s}$. Only 17 records, which are displayed in Table 2, achieved the target scaling factor limit of 5 for the acceleration spectral ordinates of the whole spectrum. The individual recordings were scaled to matcha single period, in this case at the $\operatorname{Sa}\left(T_{1}\right)$ value, as shown in Figure 6(b).

\section{Structural Models}

The building is a $3 \mathrm{D}$ frame-wall system whit posttensioned joints, modeled using wide-column concept for the frame columns at the locations of the shear walls. The possible formation of plastic hinges was considered in all members which take part in lateral resisting forces, that is, shear walls and columns. Their flexural behavior were modelled by one-component lumped plasticity elements, consisting of an elasticbeam-column and two inelastic rotational hinges at both

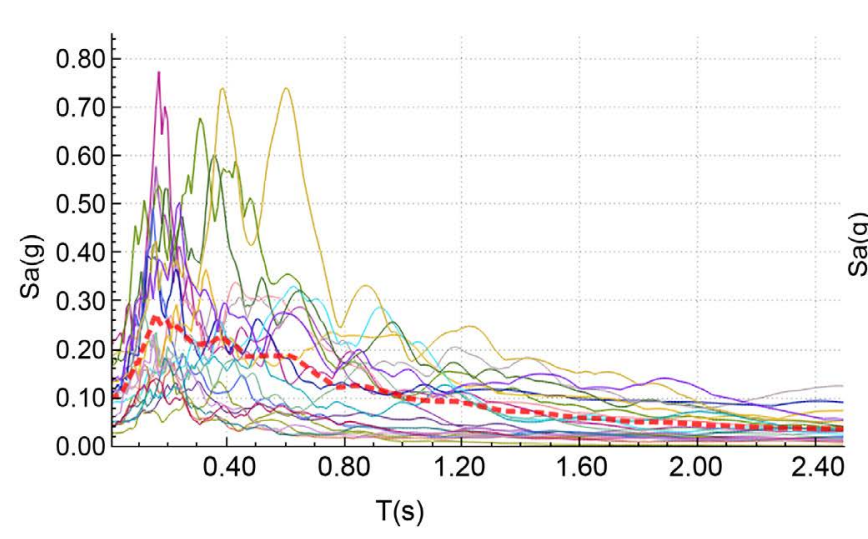

(a)

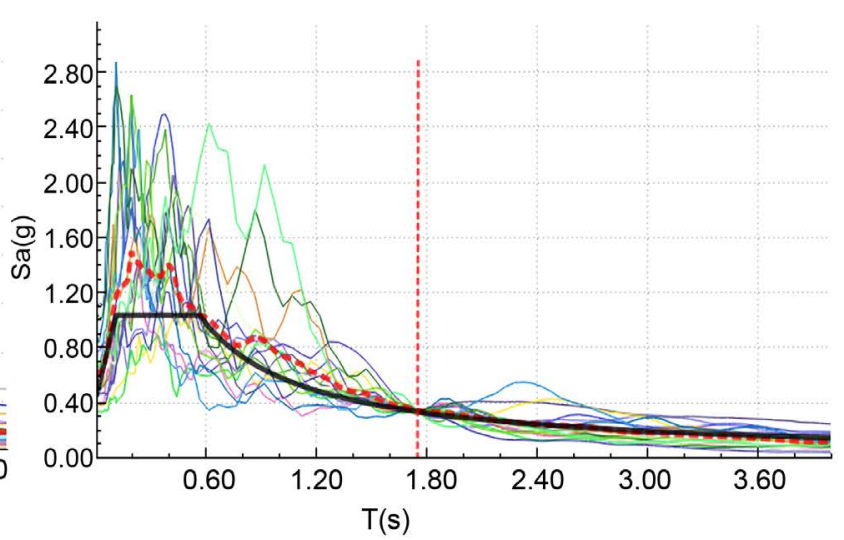

(b)

Figure 6. (a) Response spectra set of 17 records from strike-slip source mechanism to be used in IDA analysis. Unscaled signals; (b) Response spectra set of records scaled to spectral acceleration at structural period in X direction, $S a\left(T_{1}, 5 \%\right)$. 
Table 2. Set of 17 ground motion records from strike-slip mechanism.

\begin{tabular}{|c|c|c|c|c|c|}
\hline $\begin{array}{l}\text { ID } \\
\text { Record }\end{array}$ & Earthquake & Station & Date & Component & PGA (g) \\
\hline 5370 & Imperial Valley & Parachute Test Site & $31 / 10 / 1979$ & $\mathrm{Y}$ & 0.204 \\
\hline 5615 & Landers & Barstow & $30 / 06 / 1992$ & $\mathrm{X}$ & 0.131 \\
\hline 5635 & Landers & Yermo Fire Station & $30 / 06 / 1992$ & $\mathrm{X}$ & 0.245 \\
\hline 5619 & Landers & $\begin{array}{l}\text { Featherly Park-Park } \\
\text { Maint. Building }\end{array}$ & $30 / 06 / 1992$ & $\mathrm{X}$ & 0.051 \\
\hline 5270 & Borrego Mountain & San Onofre So Cal Edison & $30 / 04 / 1968$ & $\mathrm{Y}$ & 0.045 \\
\hline 5621 & Landers & Indio Coachella Canal & $30 / 06 / 1992$ & $\mathrm{Y}$ & 0.109 \\
\hline 1243 & Izmit & Yarimca-Petkim & $17 / 08 / 1999$ & $\mathrm{X}$ & 0.311 \\
\hline 5627 & Landers & North Palm Springs & $30 / 06 / 1992$ & $\mathrm{X}$ & 0.136 \\
\hline 5632 & Landers & Silent Valley Poppet Flat & $30 / 06 / 1992$ & $\mathrm{X}$ & 0.050 \\
\hline 5620 & Landers & Hemet Fire Station & $30 / 06 / 1992$ & $\mathrm{Y}$ & 0.097 \\
\hline 5351 & Imperial Valley & Coachella Canal \#4 & $31 / 10 / 1979$ & $\mathrm{X}$ & 0.115 \\
\hline 5631 & Landers & Riverside Airport & $30 / 06 / 1992$ & $\mathrm{Y}$ & 0.041 \\
\hline 5617 & Landers & Desert Hot Springs & $30 / 06 / 1992$ & $\mathrm{X}$ & 0.171 \\
\hline 5349 & Imperial Valley & Cerro Prieto & $31 / 10 / 1979$ & $\mathrm{X}$ & 0.169 \\
\hline 5371 & Imperial Valley & Plaster City & $31 / 10 / 1979$ & $\mathrm{X}$ & 0.042 \\
\hline 5626 & Landers & Morongo Valley & $30 / 06 / 1992$ & $\mathrm{X}$ & 0.188 \\
\hline 5616 & Landers & Boron Fire Station & $30 / 06 / 1992$ & $\mathrm{X}$ & 0.119 \\
\hline
\end{tabular}

ends. The moment-rotation relationship was determined according to the provisions of ASCE 41-2013 related to the performance criteria, which are implemented in SAP2000 software v20.0. Taking account the high friction forces on contact surface, due behavior induced by prestressing forces, and also the safety factor against vertical shear slip of the slab of IMS system, the joints were considered as rigid. The prestressed beams were modelled as elastic beam-column elements.

The Pushover analyses were performed for the two directions (X, Y) using one invariant lateral load pattern based on the first mode shape for each side and the roof displacement was controlled, using 100 steps. P-Delta effects were considered for all analyses. The idealized base shear force vs. top displacement relationship of the MDOF system was obtained directly from this SAP2000 v20 version, and was taken as a base to build a force-displacement for the SDOF envelope model. Figure 7 show pushover results at the moreflexible mode (X-direction). The displacements resulting from the different steps of linear and NSPs analysis are shown in Figure 8.

Using bilinear approximation obtained from MDOF modal pushover analysis the force-displacement envelope of the SDOF model was obtained by dividing the forces and displacements of the idealized pushover curve by a transformation factor $\Gamma$ (Fajfar, 2000) [15]. Table 3 shows the SDOF model parameters. 


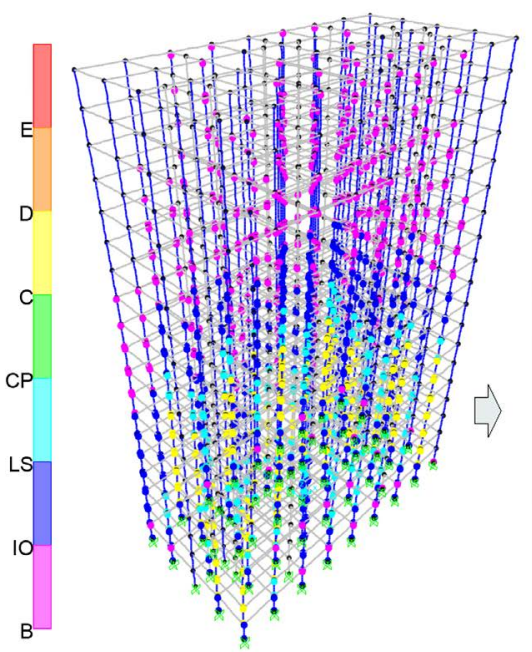

(a)

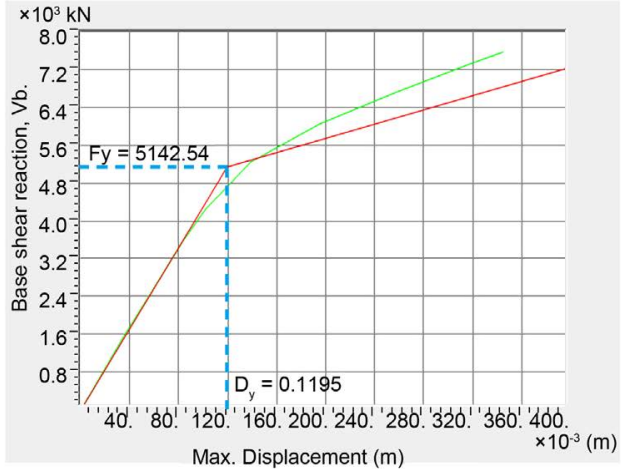

(b)

Figure 7. (a) Pushover results in direction X of structure; (b) Linearized MDOF pushover curve (obtained in SAP2000) in the X direction.

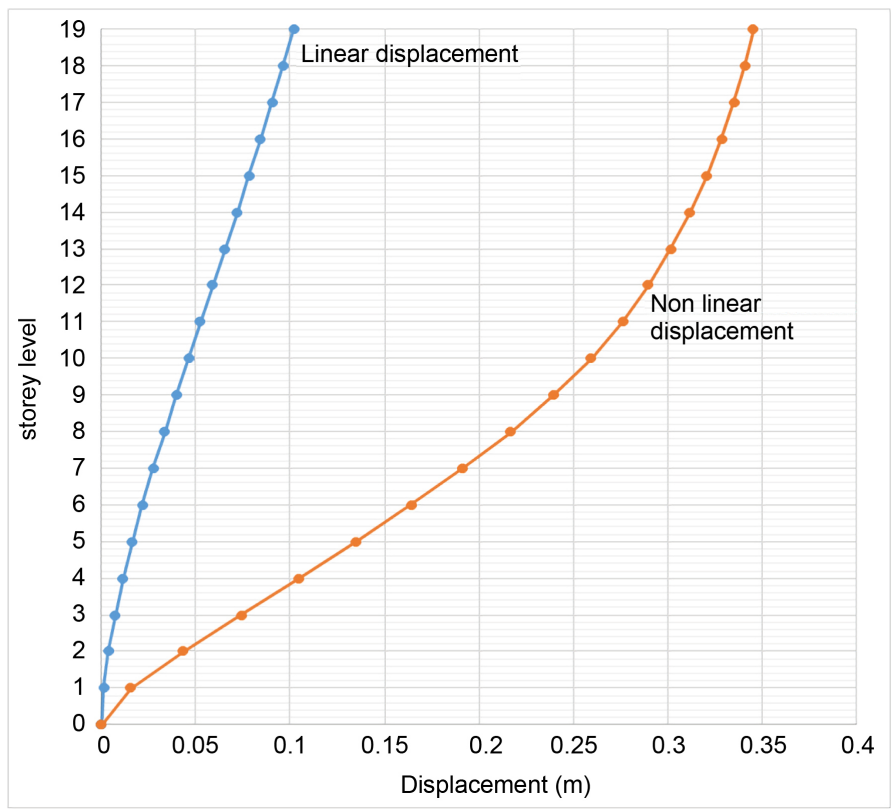

Figure 8. Linear displacement and nonlinearpushover displacement from step by step linear and pushover analysis respectively.

Table 3. Non-linear properties of the equivalent SDOF model.

\begin{tabular}{cc}
\hline Parameters of the equivalent SDOF & X-Direction \\
\hline $\mathrm{G}$ & 1.480 \\
$\mathrm{~m}^{*}\left(\mathrm{kN} \cdot \mathrm{sec}^{2} / \mathrm{m}\right)$ & 4429.653 \\
$\mathrm{~T}^{*}(\mathrm{sec})$ & 2.015 \\
$\mathrm{~F}_{\mathrm{y}}(\mathrm{kN})$ & 3477.980 \\
$\mathrm{~F}_{\mathrm{u}}(\mathrm{kN})$ & 5120.010 \\
$\mathrm{~d}_{\mathrm{y}}(\mathrm{m})$ & 0.080 \\
$\mathrm{~d}_{\mathrm{u}}(\mathrm{m})$ & 0.300 \\
\hline
\end{tabular}


To represent moderate energy dissipation capabilities incorporated into the system by post-tensioning, an idealized bilinear force-displacement relationships was used to describe the hysteretic behavior of the SDOF model following Takeda bilinear rule is selected to describe the hysteretic behavior of the SDOF model, as shown in Figure 9, i.e. non-degrading and stable hysteretic behavior without degradation of strength, but overall degradation of stiffness. To run SDOF model in OpenSees [16], using an uniaxial hysteretic material, the pinching parameters was set a value of 1 , damage parameters was set to zero and $\beta=7$ to resemble the Takeda model.

\section{Probabilistic Evaluation of Structural Response}

Dynamic Incremental Analysis, IDA, is one of the most used tools in the design and estimation of structures [17] [18] [19]. From IDA results is possible to calculate the probability of exceeding a specified level of demand, given a specified level of intensity of the hazard, i.e. fragility. The adequate selection of two parameters 1) intensity measure and 2) engineering demand are key aspects in a good analytical estimation of the seismic behavior of the structure.

Intensity Measurement (IM): The building under study classifies as a structure of moderate periods ( $\left.T_{1}=1.75 \mathrm{~s}\right)$. Many other IM have been suggested by different authors [20] [21] [22] [23] [24] as a ground motion intensity parameter for scaling signals. Spectral acceleration at first period of structures, $\mathrm{Sa}\left(T_{1}\right)$ usually results in less dispersion, and PGA has been also considered for the authors, because the seismic hazard map is defined in terms of PGA. Taking advantage of IDA procedure by mean of which, once a Structural Response Measure (SRM) is obtained given a specified level of intensity, other IMs of ground motion can be found at this level that could be correlated to damage as well.

Structural Response Measure (SRM): The displacement of the equivalent SDOF model was used as a measure of the structural response to check the limit

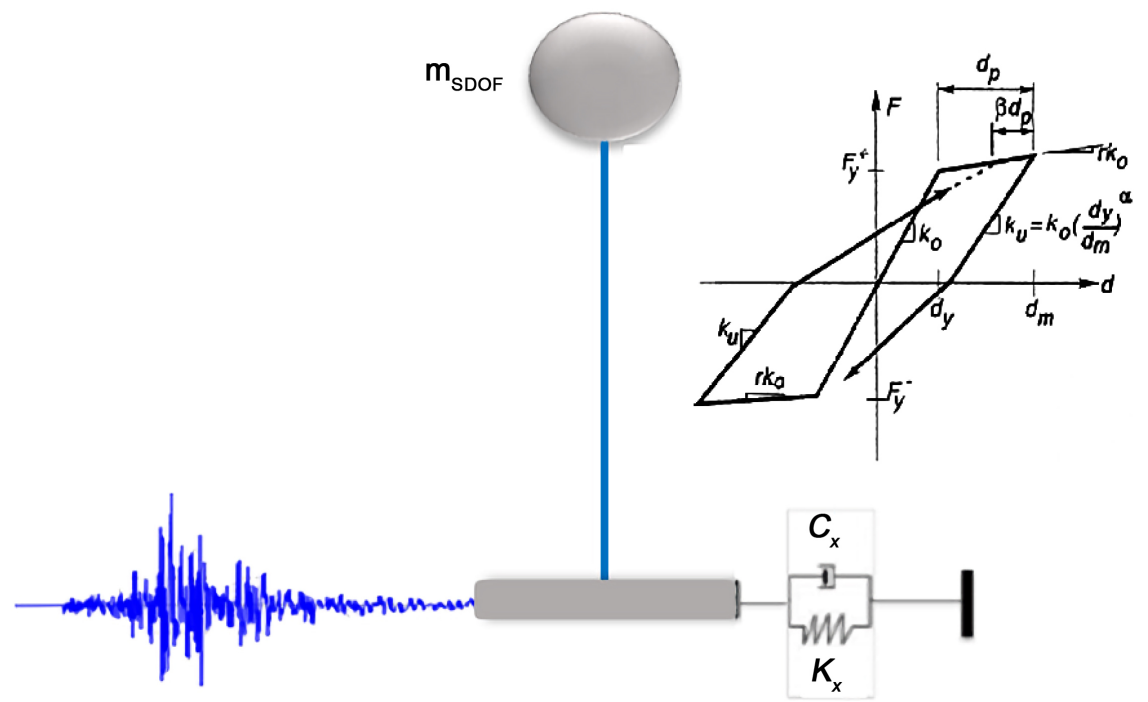

Figure 9. SDOF model in X direction, following Takeda hysteretic rule. 
state of collapse to represent in terms of IDA curves and its fractile the structural response of a substitute oscillator with dynamic characteristics of equivalent to the actual structure [25] [26] [27].

This simple oscillator, was subjected to a set of ground motions in both directions by separate to simulate the response of the system under records scaled to the earthquake hazard of the site, using as intensity measure $S a\left(T_{1}, 5 \%\right)$. A routine developed by Vamvatsikos, 2002 [28] [29] [30] for the calculation of IDA curves and fractile curves was adapted to the particularities of our analysis and used for this purpose.

The results obtained from the IDAs were translated into IDA curves, that is, a plotting of $I M$ vs. Structural Response Measure (SRM) from which to take outsome conclusions about global dynamic capacity of surrogate structure. Figure 10 shows IDA curves as a function of maximum displacement level achieved at the top of equivalent SDOF for each individual record under increasing levels of peak ground acceleration (PGA).

The collapse intensity for each record is defined just as the flat line begins, indicating a trend towards infinite displacements. A lognormal function of distribution of $S a\left(T_{1}\right)$ values was assumed. As shown in figure Figure 11, the randomness in the response induced by the records has been summarized in the fractile lines of capacity in terms of intensity measure, $\operatorname{IM}_{(16 \%, 50 \%, 84 \%)}^{\mathrm{C}}$.

Central value (median) and dispersion measures (standard deviation) of IDA results could be summarized by means of fractile curves based on IM values $\left(\mathrm{IM}_{16 \%}, \mathrm{IM}_{50 \%}\right.$ and $\left.\mathrm{IM}_{84 \%}\right)$ of the near collapse limit state as shown in Figure 12. This $\mathrm{IM}^{\mathrm{C}}$ is also expressed as non-dimensional collapse capacity defined in terms of $\mathrm{Sa}(T)_{1} / g \gamma$ versus ductility, where $\gamma=f_{y} /(\mathrm{mg})$.

Fragility curve, which expresses the conditional probability of failure $\left(P_{f}\right)$ of a structure given a ground motion intensity measure (e.g., peak ground acceleration (PGA) or Spectral acceleration $(\mathrm{Sa})$ ) have been obtained using Incremental

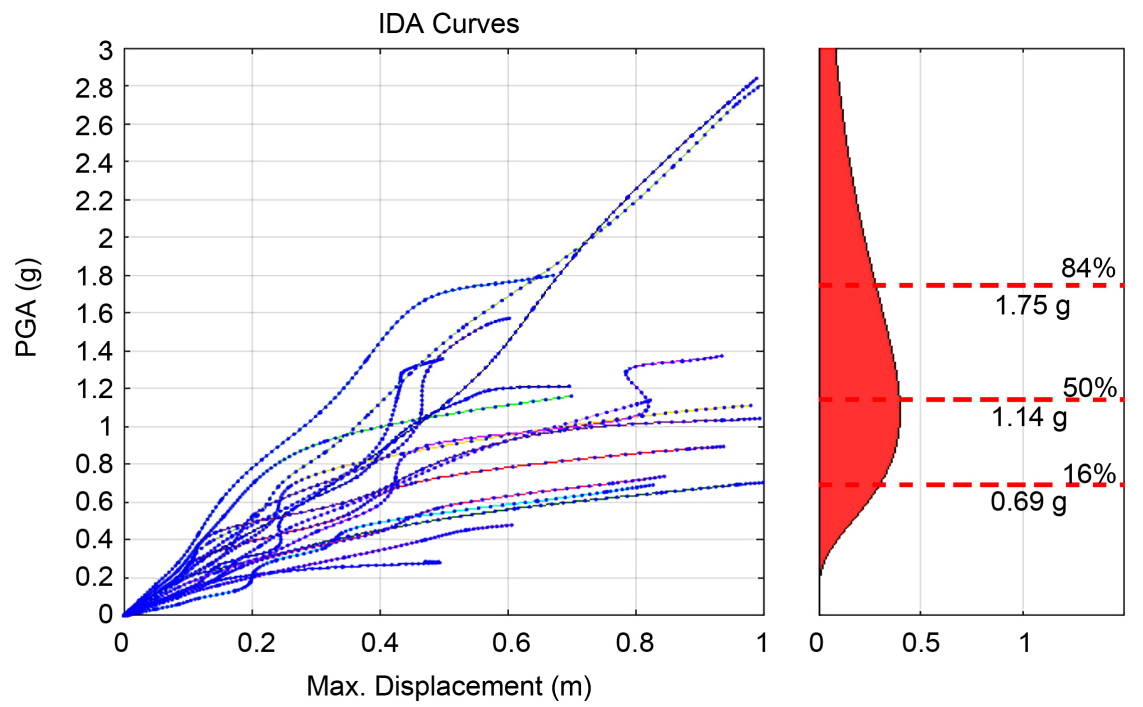

Figure 10. IDA curves in terms of maximum displacement demand versus PGA. 

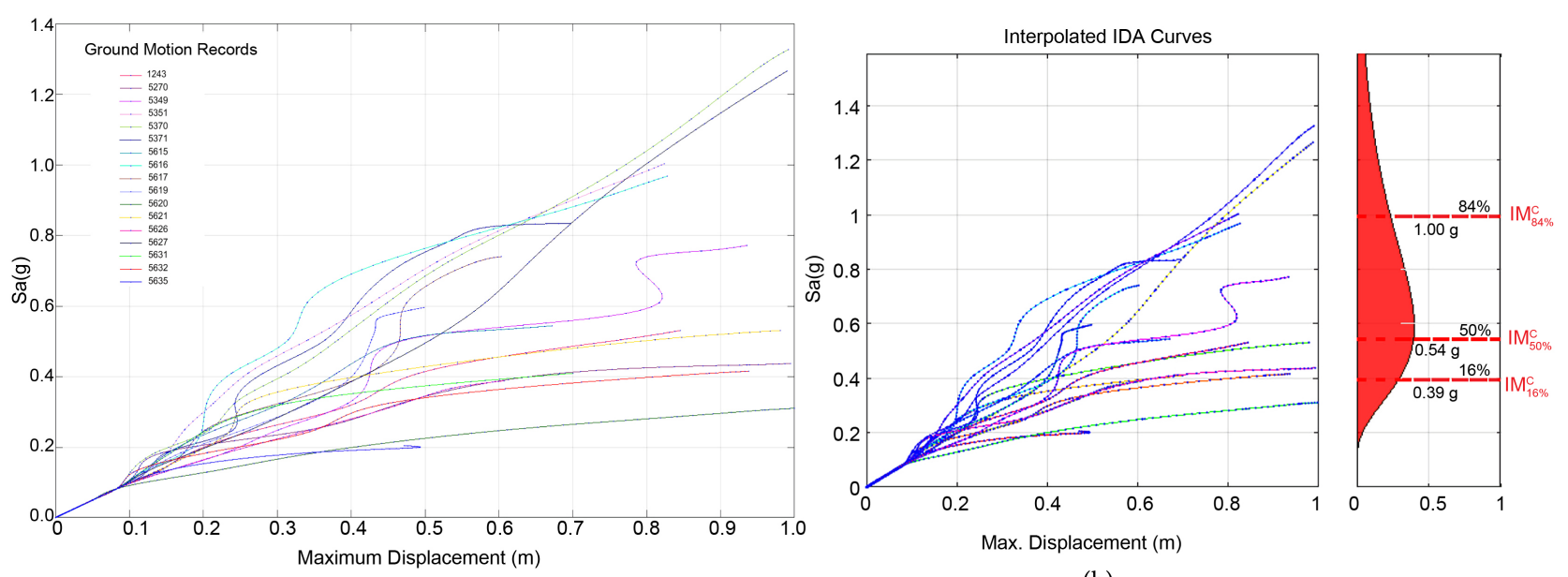

(b)

Figure 11. IDA curves in terms of maximum displacement demand versus $S a\left(T_{1}\right)$. (a) IDA curves of individual records, (b) with $\mathrm{IM}^{\mathrm{C}}$ fractile $16 \%, 50 \%$ and $84 \%$ curves superposed.

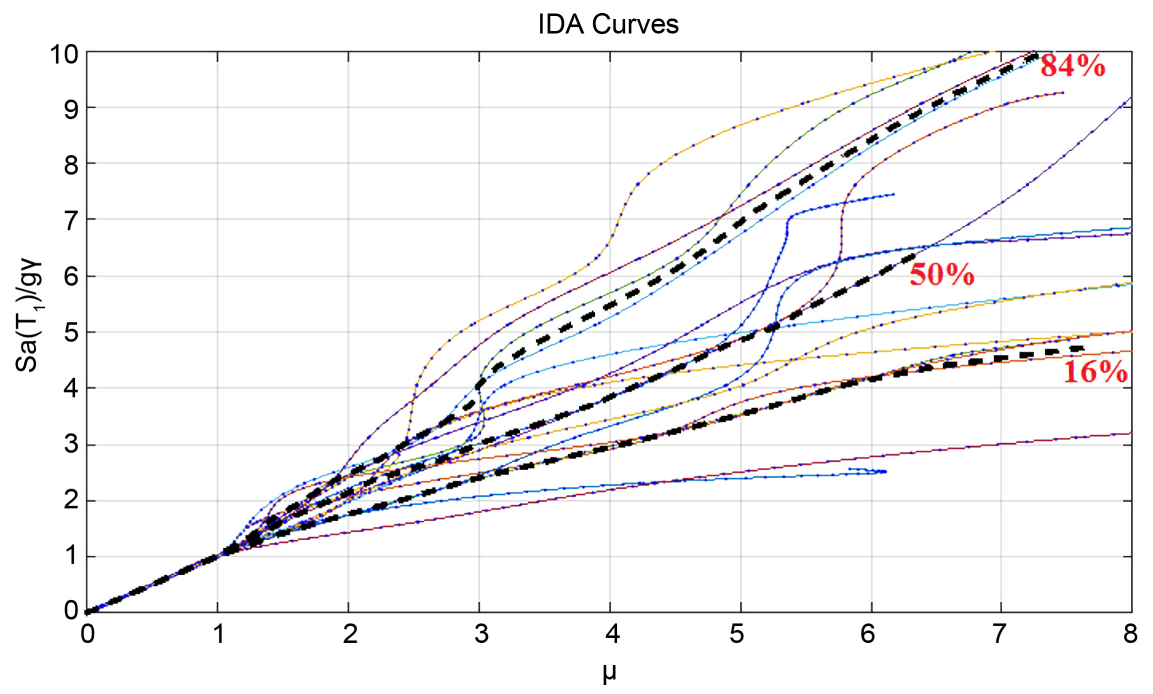

Figure 12. Individuals IDA curves and fitted IDA curves for different quantile (16\%, 50\% and $84 \%$ ) defined in terms of non-dimensional collapse capacity defined as $S a(T)_{1} / g \gamma$ versus ductility.

Dynamic Analyses and results of the pushover analyses. Fragility curve shown in the Figure 13, correspond to $\mathrm{X}$ direction. A lognormal distribution function was fitted to the collapse data to estimate collapse capacity in terms of either IM or DM used to construct the IDA curves. The median collapse capacity in terms of $S a\left(T_{1}\right)$ of $0.54 \mathrm{~g}$ exceeded design $S a\left(T_{1}\right)=0.33 \mathrm{~g}$ for the considered return period $(\operatorname{Tr}=1642$ years). For the equivalent SDOF model, a collapse margin ratio of collapse, $\mathrm{CMR}=1.62$ was found.

\section{Conclusions}

An approach to probabilistic structural analysis, which combined nonlinear static (pushover) analysis of entire structure and nonlinear response history 


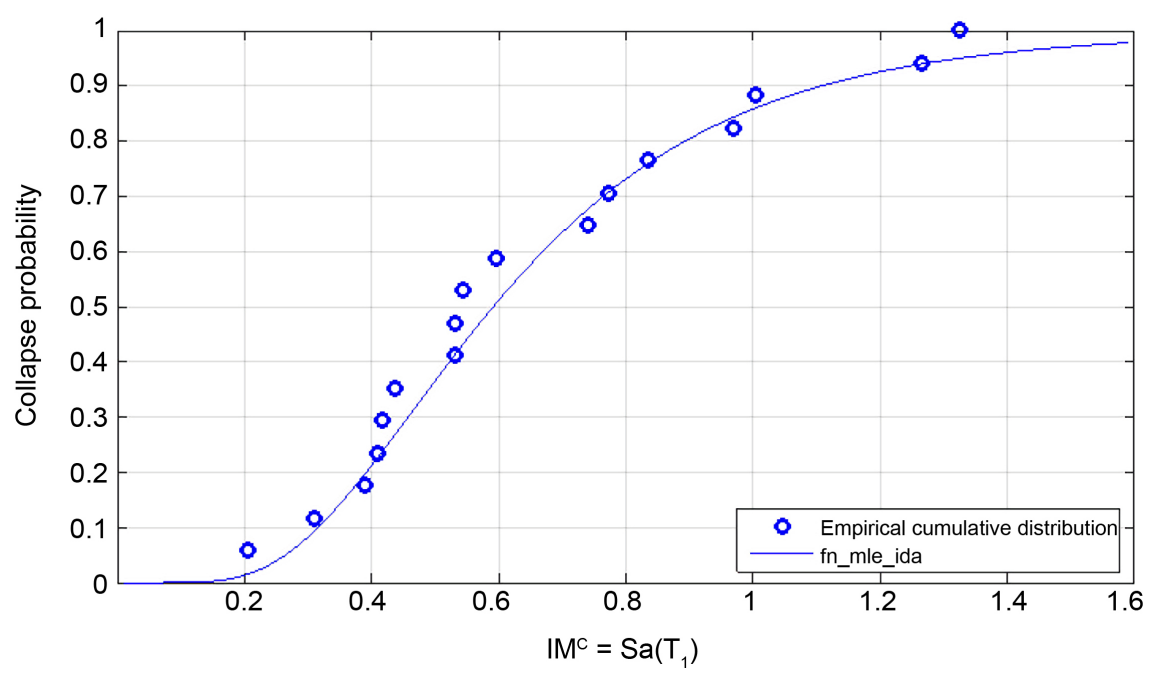

Figure 13. Fragility collapse curve from IDA data.

analysis (NRHA) of an equivalent single-degree-offreedom (SDOF) model was presented. The main parameter of interest obtained from the IDA was the median collapse level acceleration, $\hat{S}_{C}$. It is the value at which $50 \%$ of the ground motion records have collapsed. The value of $\hat{S}_{C}=0.54 \mathrm{~g}$ was found higher than the specified by the new standard for the MCE intensity, that is $\operatorname{Sa}\left(T_{1}\right)_{1642 y}=$ 0.335 g. A collapse margin ratio was found of $\mathrm{CMR}=1.62$.

In Cuba there are no guidelines that regulate the ratio of collapse margin through some acceptable value in existing buildings. Although it exists in the scientific literature, e.g., FEMA p695, given values of acceptance. We cannot automatically infer the accuracy and adequacy of the values obtained until a $3 \mathrm{D}$ simulation of the structure is performed taking into account the update of the current structural condition, in short, a "benchmark" building is needed against which to contrast any results obtained from simplified models. This will be the subject of our next study.

\section{Recommendations}

The advantage, still unexplored by our standard, of incorporating the results of tests and surveys in the procedures of global analysis of structures, with the aim of being able to reduce the degree of uncertainty that currently characterizes structural response evaluations opens up a set of new questions related to the influence of deterioration and ageing on these structures and their possible influence on the modification of structural capacity and safety, an issue that can be analyzed in a future investigation.

\section{Acknowledgements}

The seismic safety assessment of the structural systems, to which the results of our research respond, was approved under the project: "Assessing structural vulnerability associated with seismic hazard in different types of multi-family housing buildings" inserted in the Disaster Reduction Programs, with the sup- 
port of the National Civil Defense and approved by the Cuban Ministry of Science and Technology. We would also like to thank Professor Dr. Carlos Recarey Morfa, director of the Center for the Study of Computational Mechanics and Numerical Methods in Engineering. CIMNE Classroom. University of Las Villas Marta Abreu for their constant collaboration, advice and funding in all our research work.

\section{Conflicts of Interest}

The authors declare no conflicts of interest regarding the publication of this paper.

\section{References}

[1] NC-46 (2017) Construcciones Sismo Resistentes. Requisitos básicos para el diseño y construcción, Cuba. Comité Estatal de Normalización.

[2] Holický, M., et al. (2013) Basics for Assessment Existing Structures. Milan Klokner Institute, Czech Technical University in Prague, Czech Republic.

[3] Arango, E.D. (2014) Análisis sismo-tectónico del territorio oriental de Cuba a partir de la integración del modelo de corteza $3 \mathrm{D}$ de datos gravimétricos con datos sismológicos y geodésicos. Phd Centro de Investigación científica y de educación superior de Ensenada, Baja California.

[4] García, J.A. (2007) Estimados de peligrosidad sísmica con el errores asociados para Cuba, y cálculo de pérdidas para la ciudad de Santiago de Cuba usando técnicas SIG. PhD Centro Nacional de Investigaciones Sismológicas Instituto de Geofísica y Astroomía. Ministerio de Ciencia, Tecnología y Medio Ambiente. La HabanaTrieste.

[5] Alvarez, L., Villalón, M. and Lindholm, C. (2015) Informe principal de la Tarea 2. Peligrosidad sísmica, principios y herramientas. Noruega-Cuba. Centro Nacional de Investigaciones Sismológicas. Cuba.

[6] Naein, F., Alimoradi, A. and Pezeshk, S. (2004) Selection and Scaling of Ground Motion Time Histories for Structural Design Using Genetic Algorithms. Earthquakes Spectra, 20, 413-426. https://doi.org/10.1193/1.1719028

[7] Fahjan, Y.M. and Ozdemir, K. (2007) Procedures for Real Earthquake Time Histories Scaling Application to Fit Iranian Design Spectra. V Internacional Conference of Seismology and Earthquake Engineering, Teheran, May 2007.

[8] Chang, S.M., Ruiz, S.E. and Montiel, M.A. (2005) Escalamiento de acelerogramas y número mínimo de registros requerido para el análisis de estructuras, Revista de Ingeniería Sísmica, enero-junio, número 072. Sociedad mexicana de Ingeniería sísmica, AC, Distrito Federal, México.

[9] Atkinson, G.M. (2009) Earthquake Time Histories Compatible with the 2005 NBCC Uniform Hazard Spectrum. Canadian Journal of Civil Engineering, 36, 991-1000. https://doi.org/10.1139/L09-044

[10] Shahrouzi (2011) A New Irbid Genetic and Swarm Optimization for Earthquake Accelerogram Scaling. International Journal of Optimization in Civil Engineering, $1,127-140$.

[11] Reyes, J.C. and Kalkan, E. (2001) Número de registros sísmicos requeridos para el procedimiento de escalamiento ASCE, Memorias del V Congreso Nacional de Ingeniería Sísmica, Medellín, Colombia. 
[12] Dhakal, R.P., Singh, S. and Mander, J.B. (2007) Effectiveness of Earthquake Selection and Scaling Method in New Zealand. Bulletin of the New Zealand Society for Earthquake Engineering, 40, 160-171.

[13] Pacific Earthquake Engineering Research Center (2005) PEER Strong Motion Database on Line. Berkley. https://peer.berkeley.edu/peer-strong-ground-motion-databases

[14] ISESD Data Bank of the Project CD ROM (2004) Disemination of European Strong Motion Database. (Europa y Oriente Medio). Collaboration of N. N. Ambraseys and, J. Douglas from Dept. of Civil \& Environmental Engineering, Imperial College of Science, Technology \& Medicine, London.

[15] Fajfar, P. (2000) A Nonlinear Analysis Method for Performance Based Seismic Design. Earthquake Spectra, 16, 573-592. https://doi.org/10.1193/1.1586128

[16] McKenna, F., Fenves, G.L. and Scott, M.H. (2003) Open System for Earthquake Engineering Simulation. Pacific Earthquake Engineering Research Center, University of California, Berkeley. http://opensees.berkeley.edu

[17] Lin, T. and Baker, J.W. (2013) Introducing Adaptive Incremental Dynamic Analysis: A New Tool for Linking Ground Motion Selection and Structural Response Assessment. 11 th International Conference on Structural Safety \& Reliability, New York, 16-20 June 2013, 805-811.

[18] Brozovič, M. and Dolšek, M. (2011) Computational Efficiency of Progressive Incremental Dynamic Analysis. 3rd ECCOMAS Thematic Conference on Computational Methods in Structural Dynamics and Earthquake Engineering, 25-28 May 2011.

[19] Padgett, J.E., et al. (2008) Earthquake Engineering and Structural Dynamics. Wiley InterScience, Hoboken. http://www.interscience.wiley.com

[20] Conte, J.P. (2003) Ground Motion Intensity Measures for Performance-Based Earthquake Engineering. Proceedings of the 9th International Conference on Applications of Statistics and Probability in Civil Engineering, San Francisco, 6-9 July 2003.

[21] Baker, J.W. and Cornell, C.A. (2005) A Vector-Valued Ground Motion Intensity Measure Consisting of Spectral Acceleration and Epsilon. Earthquake Engineering and Structural Dynamics. Wiley, Hoboken. http://www.interscience.wiley.com https://doi.org/10.1002/eqe.474

[22] Haselton, C.B. and Baker, J.W. (2006) Ground Motion Intensity Measures for Collapse Capacity Prediction: Choice of Optimal Spectral Period and Effect of Spectral Shape. 8NCEE, San Francisco, April 2006.

[23] Bojórquez, E., et al. (2012) Comparing Vector-Valued Intensity Measures for Fragility Analysis of Steel Frames in the Case of Narrow-Band Ground Motions. Engineering Structures, 45, 472-480. https://doi.org/10.1016/j.engstruct.2012.07.002

[24] Bianchini, M., Diotallevi, P.P. and Landi, L. (2008) Influence of Earthquake Intensity Measure on the Probabilistic Evaluation of RC Buildings. 14th World Conference on Earthquake Engineering, Beijing, 12-17 October 2008.

[25] Majid Baradaran, S. (2013) Collapse Assessment of Concrete Buildings: An Application to Non-Ductile Reinforced Concrete Moment Frames.

[26] NIST GCR 10-917-7 (2010) Program Plan for the Development of Collapse Assessment and Mitigation Strategies for Existing Reinforced Concrete Buildings.

[27] CNR-DT 212 (2014) Guide for the Probabilistic Assessment of the Seismic Safety of Existing Buildings. CNR of Italy.

[28] Vamvatsikos, D. and Cornell, C.A. (2002) Tracing and Post-Processing of IDA 
Curves: Theory and Software Implementation. Report No. RMS-44, RMS Program, Stanford University, Stanford.

[29] Vamvatsikos, D. and Cornell, C.A. (2005) Seismic Performance, Capacity and Reliability of Structures as Seen through Incremental Dynamic Analysis. John $A$. Blume Earthquake Engineering Center Technical Report 151, Standford Digital Repository. https://purl.stanford.edu/qs357yj1571

[30] Vamvatsikos, D. and Fragiadakis, M. (2009) Incremental Dynamic Analysis for Estimating Seismic Performance Sensitivity and Uncertainty. Earthquake Engineering and Structural Dynamics, 39, 141-163. https://doi.org/10.1002/eqe.935 